University of Nebraska - Lincoln

DigitalCommons@University of Nebraska - Lincoln

Mammalogy Papers: University of Nebraska

State Museum

Museum, University of Nebraska State

$5-1-1980$

\title{
Evolutionary Origin of Eptesicus lynni
}

Michael L. Arnold

Texas Tech University, Lubbock, TX

Robert J. Baker

Texas Tech University, rjbaker@ttu.edu

Hugh H. Genoways

University of Nebraska - Lincoln, h.h.genoways@gmail.com

Follow this and additional works at: https://digitalcommons.unl.edu/museummammalogy

Part of the Biodiversity Commons, Other Ecology and Evolutionary Biology Commons, and the Zoology Commons

Arnold, Michael L.; Baker, Robert J.; and Genoways, Hugh H., "Evolutionary Origin of Eptesicus lynni" (1980). Mammalogy Papers: University of Nebraska State Museum. 67.

https://digitalcommons.unl.edu/museummammalogy/67

This Article is brought to you for free and open access by the Museum, University of Nebraska State at DigitalCommons@University of Nebraska - Lincoln. It has been accepted for inclusion in Mammalogy Papers: University of Nebraska State Museum by an authorized administrator of DigitalCommons@University of Nebraska Lincoln. 


\section{EVOLUTIONARY ORIGIN OF EPTESICUS LYNNI}

Currently, three species of bats of the genus Eptesicus (fuscus, guadeloupensis, and lynni) are recognized as occurring on islands in the Antilles. Of these, E. fuscus and E. guadeloupensis are believed to belong to the fuscus-group of the genus (Davis, 1966; Genoways and Baker, 1975). However, the status and relationships of E. lynni are unclear. Shamel (1945) described lynni as a member of the brasiliensis-group. On the other hand, Sanborn (1941) considered three earlier specimens of lynni as members of the subspecies E. fuscus hispaniolae (we have examined the Sanborn specimens and they are referable to lynni). Baker and Genoways (1978) stated that with available data it could not be determined whether lynni evolved from a fuscus or brasiliensis progenitor. The current study was designed to determine the genic similarities of E. lynni to E. fuscus of the fuscus-group and E. brasiliensis and E. diminutus of the brasiliensis-group in an attempt to understand better the origin of this endemic Antillean species.

Materials and methods.-Cpecimens examined were E. lynni (2 $\left.+\%, 2 \delta^{\circ}\right)$, Jamaica, St. Ann Parish, Green Grotto; E. diminutus (1 $q, 4$ o $\left.\delta^{\star}\right)$, Venezuela, Guarico, $45 \mathrm{~km} \mathrm{~S}$ Calabozo; $E$. brasiliensis (1 ९), Venezuela, Miranda, Parque Nacional Guatopo, Aqua Blanca; and E. fuscus $\left(8 \uparrow q, 2 \delta^{\star}\right)$, Massachusetts, Middlesex Co., Lexington; (5 $\left.q, 4 \delta^{\star}\right)$, Georgia, Clarke Co., Athens. Voucher specimens are deposited as follows: Carnegie Museum of Natural History, lynni; The Museum, Texas Tech University, all fuscus and two diminutus; Division de Fauna, Ministerio del Ambiente y de los Recursos Naturales Renovables, Caracas, Venezuela, three diminutus and one brasiliensis.

Methods for tissue preparation and starch gel electrophoresis and enzyme designations are similar to those of Selander et al. (1971) as modified by Greenbaum and Baker (1976). Nineteen presumptive loci, consisting of both enzymatic and nonenzymatic proteins, were assayed. Lactate dehydrogenase-1 and -2, Phosphoglucose isomerase-1 and -2, Albumin, Isocitrate dehydrogenase-1 and -2, Malate dehydrogenase-1 and -2, Phosphoglucomutase-1 and -2, 6-Phosphogluconate dehydrogenase, and Peptidase were resolved on a tris citrate $\mathrm{pH} 6.7$ continuous buffer system. The substrate for the Peptidase stain was the dipeptide Glycyl-L-Leucine. $\alpha$-Glycerophosphate dehydrogenase, Glutamate dehydrogenase, Leucine aminopeptidase, and Glutamate Oxalate transaminase-1 and -2 were resolved using a tris citrate $\mathrm{pH} 8.0$ continuous buffer system. Hemoglobin was resolved on a tris maleate pH 7.4 continuous buffer system. 


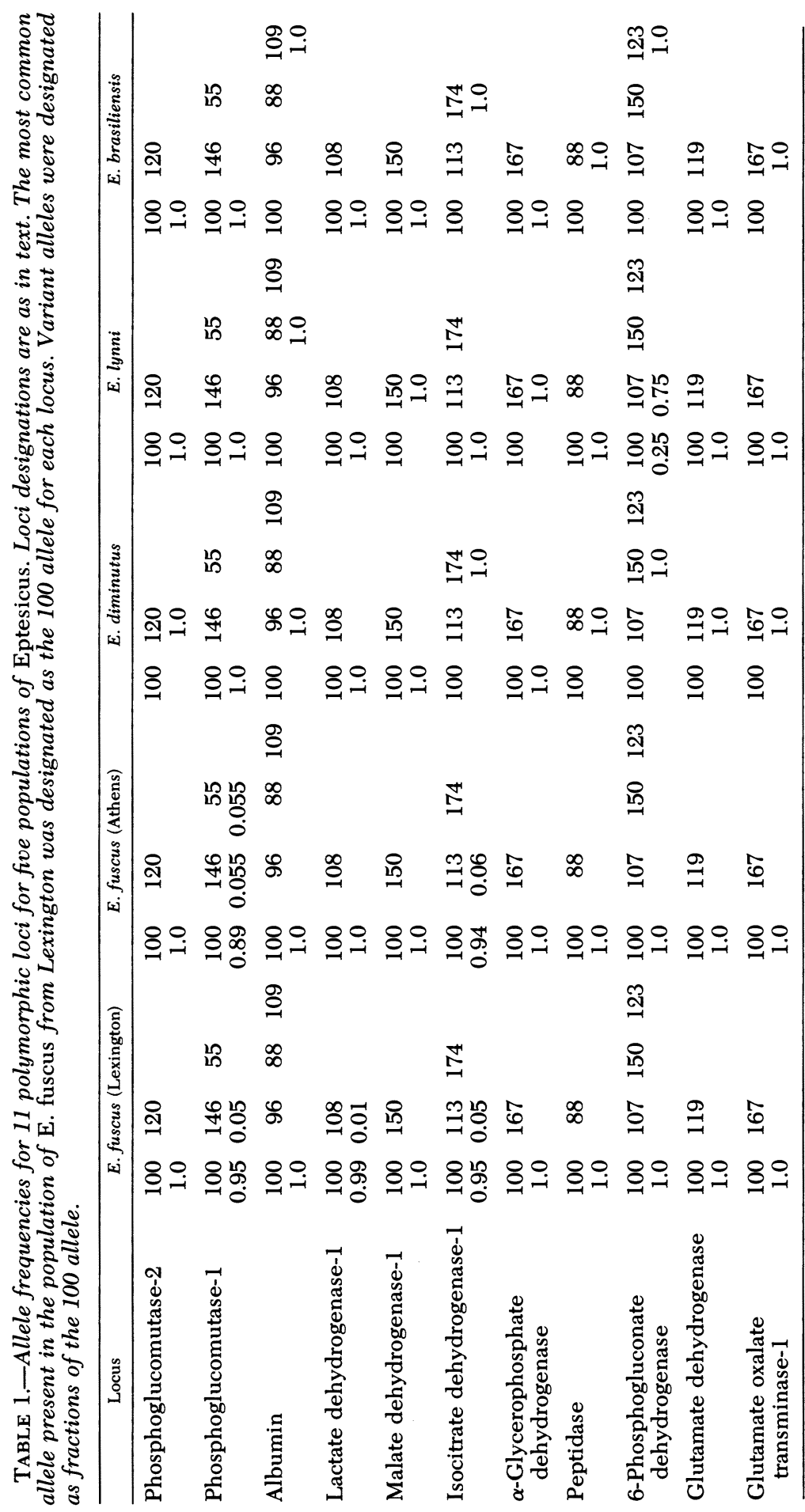




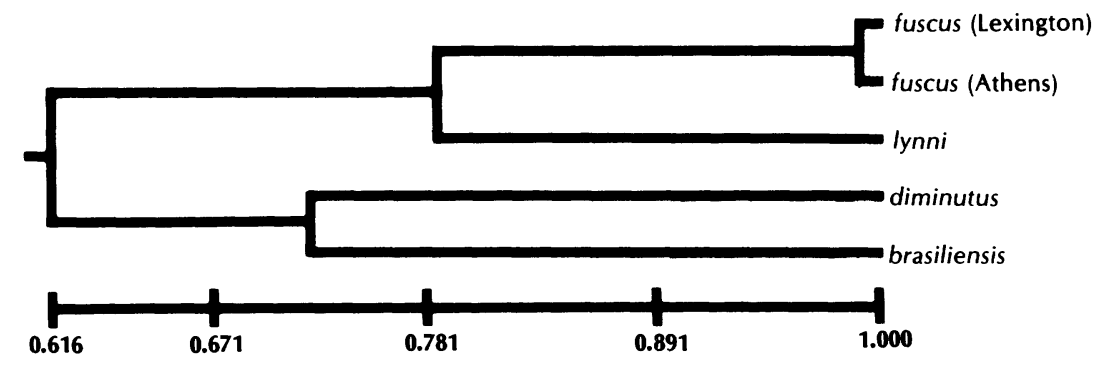

FIG. 1.-Genic similarities for four species of Eptesicus.

Electromorph (allele) frequencies (eight loci were monomorphic for all four taxa and the frequency of the other 11 loci are given in Table 1) calculated directly from banding patterns present on the electrophoretic gels were used to generate Rogers' similarity (Rogers, 1972) values, which were utilized to produce a phenogram of genetic similarities (Fig. 1). The generation of the phenogram was based on the UPGMA option given by Rohlf and Kishpaugh (1972).

Results and discussion.-As indicated by Fig. 1, two species clusters are formed on the basis of genic similarity coefficients. The upper species group includes the two populations of $E$. fuscus, which are genically very similar $(\overline{\mathrm{S}}=.993)$, and the population of $E$. lynni, which shares approximately $80 \%$ of its alleles $(\overline{\mathrm{S}}=.794)$ with the fuscus samples. At an average similarity value of .616 the populations of E. diminutus and E. brasiliensis separate from the other two species. The diminutus and brasiliensis samples share an $\overline{\mathrm{S}}$ value of .737. These genic coefficients generally agree with the currently accepted taxonomic relationships of these species (Williams, 1978). Our sample indicates much lower amounts of genic similarity between lynni and either brasiliensis or diminutus than is found between lynni and fuscus.

The range of coefficients found in our study is in concordance with previously reported intraand interspecific values in the bat families Vespertilionidae (Straney et al., 1976) and Phyllostomatidae (Straney et al., 1979). In addition, comparisons of other vertebrate populations have yielded similar values (Avise, 1974). Based upon findings in recent studies (Sarich, 1977; Gorman and Renzi, 1979), no significant changes in $\overline{\mathrm{S}}$-values would be expected if the population sample sizes were increased.

In conclusion, genic data indicate the most likley origin of E. lynni is from the E. fuscus complex. Intraspecific populations generally differ at an average of $15 \%$ or less of their electrophoretically detectable loci (Avise, 1974). Eptesicus lynni is divergent from E. fuscus at approximately $20 \%$ of the loci examined, which does not lend support to the conclusion that lynni is conspecific with fuscus. Before final conclusions are reached on this matter, a genic comparison between $E$. $f$. hispaniolae and E. lynni is needed.

Acknowledgments.-For assistance in collecting, we thank J. W. Bickham, P. V. August, L. August, J. C. Patton, and C. Burnett. For logistical support in Venezuela, we thank Dr. R. Orta and Sr. T. Blohm. M. Bogan critically evaluated the manuscript. D. F. Williams assisted in identification of specimens. This study was supported by National Science Foundation grant number DEB 76-20580, and the Institute of Museum Research. The Jamaican field work was supported by M. Graham Netting Research Fund, Carnegie Museum of Natural History, through a grant from the Cordelia Scaife May Charitable Trust. Venezuelan field work was supported by an International Environmental Sciences Program awarded to J. Eisenberg.

\section{LITERATURE CITED}

AvISE, J.C. 1974. Systematic value of electrophoretic data. Syst. Zool., 23:465-481.

BAKER, R. J., AND H. H. GeNOWAYS. 1978. Zoogeography of Antillean bats. Pp. 53-97, in Zoogeography in the Caribbean (F. B. Gill, ed.). Spec. Publ. Philadelphia Acad. Sci., 13:1-128.

$\rightarrow$ DAVIS, W. B. 1966. Review of South American bats of the genus Eptesicus. Southwestern Nat., 11:245-274.

GenOWAYS, H. H., AND R. J. BAKER. 1975. A new species of Eptesicus from Guadeloupe, Lesser Antilles (Chiroptera: Vespertilionidae). Occas. Papers Mus., Texas Tech Univ., $34: 1-7$.

Gorman, G.C., AND J. RenZI, Jr. 1979. Ge- 
netic distance and heterozygosity estimates in electrophoretic studies: effects of sample size. Copeia, 1979:242-249.

GreenbaUm, I. F., AND R. J. BAKER. 1976. Evolutionary relationships in Macrotus (Mammalia: Chiroptera); biochemical variation and karyology. Syst. Zool., 25:15-25.

Rogers, J. S. 1972. Measure of genetic similarity and genetic distance. Univ. Texas Publ., 7213:145-153.

Rohlf, F. J., AND J. Kishpaugh. 1972. Numerical taxonomy system of multivariate statistical programs. The State Univ. of New York at Stony Brook, Stony Brook, New York, $87 \mathrm{pp}$

SANBORN, C. C. 1941. Descriptions and records of Neotropical bats. Field Mus. Nat. Hist., Zool. Ser., 27:371-387.

SARICH, V. M. 1977. Rates, sample size and the neutrality hypothesis for electrophoresis in evolutionary studies. Nature, 265:24-28.

SELANDER, R. K., ET AL. 1971. Biochemical polymorphism and systematics in the genus
Peromyscus. I. Variation in the old-field mouse (Peromyscus polionotus). Studies Genetics VI, Univ. Texas Publ., 7103:49-90.

Shamel, H. H. 1945. A new Eptesicus from Jamaica. Proc. Biol. Soc. Washington, 58:107110.

Straney, D. O., M. H. Smith, R. J. Baker, AND I. F. Greenbaum. 1976. Biochemical variation and genic similarity of Myotis velifer and Macrotus californicus. Comp. Biochem. Physiol., 54B:243-248.

Straney, D. O., M. H. Smith, I. F. GreenBAUM, AND R. J. BAKER. 1979. Biochemical genetics. Pp. 157-176, in Biology of bats of the New World family Phyllostomatidae, Part III (R. J. Baker, J. K. Jones, Jr., and D. C. Carter, eds.). Spec. Publ. Mus., Texas Tech Univ., 16:1-441.

Williams, D. F. 1978. Taxonomic and karyological comments on small brown bats, genus Eptesicus, from South America. Ann. Carnegie Mus., 16:361-383.

Michael L. ARnOl' ${ }^{1}$, R. J. BAKER', AND H. H. GenOways', ${ }^{1}$ Department of Biological Sciences and The Museum, Texas Tech University, Lubbock, TX 79409, and '2Section of Mammals, Carnegie Museum of Natural History, 4400 Forbes Ave., Pittsburgh, PA 15213. Submitted 2 April 1979. Accepted 15 November 1979. 